\title{
Calvyn en die ekumene
}

\author{
F J VAN ZYL
}

\section{Inleiding}

As 'n mens dink aan die internasionale kerklike byeenkomste vanaf Edinburgh in 1910 tot Nairobi in 1975, 'n pad wat loop oor Jerusalem, Tambaram, Amsterdam, Evanston, Nieu-Delhi, Mexico-Stad, Geneve, Uppsala en Bankok, is dit seker korrek om die twintigste eeuse kerkgeskiedenis te karakteriseer as die eeu van ekumeniese bemoeienisse. Ons Kerk het die ekumeniese pad saam met die Wêreldraad van Kerke geloop vanaf 1948 tot 1961. Sedertdien het ons slegs lidmaatskap behou van daardie groep Protestantse kerke wat die prebiteriale stelsel handhaaf, terwyl ons in 1976 die Gereformeerde Ekumeniese sinode in waarnemershoedanigheid bygewoon het. Nie net in Suid-Afrika nie, maar ook in sekere Lutherse kringe in Duitsland het daar in die jongste tyd 'n definitiewe reaksie gekom teen die rigting wat die grootste Ekumeniese instelling van hierdie eeu, naamlik die Wêreldraad van kerke, ingeslaan het. Die bedoeling van hierdie studie is nie om die ekumeniese bemoeienisse van Calvyn te vergelyk met die van die Wêreldraad van Kerke en ander ekumeniese organisasies van ons tyd nie. Die basiese gedagtes van Calvyn oor die ekumeniese taak van die kerk soos wat dit tot openbaring gekom het in sy bemoeienisse, kan egter kritiserend, korrigerend en rigtingwysend aangewend word in 'n tyd van ontsaglike groot ekumeniese verwarring. Dit is verbasend hoe aktueel Calvyn se teologiese beskouings vir die ekumeniese strewe van ons tyd is.

\section{Die betekenis van ekumene}

Ekumene of ekumenies is woorde en begrippe wat vandag swaar belas is. Daarom is dit nodig dat 'n mens vooraf eers rekenskap gee van wat met hierdie woorde bedoel word. Peter Beyerhaus (Ökumene im Spiegel von Nairobi p $309^{\prime} 75$ ) reken dat die grond van die kwaad geleë is in die begrip Oikumene self, omdat dit van heidense oorsprong is. Aristoteles en sy leerling Alexander die Grote het onder hierdie begrip ' $n$ ryk verstaan van mense van goeie wil. In hierdie ryk sal die verligting van gelykgesindes en regverdiges die duisternis van eiesinnige en eiewillige barbare beëindig (Plutarhus, aangehaal deur J W Winterhager in DIE UMWÄLZUNG IN DER ÖKUMENE, s 3).

Met verwysing na die Nuwe Testamentiese gegewens, wys Beyerhaus op twee betekenisse van die woord oikouméne: 
(i) die bewoonde wêreld waarmee eintlik die Grieks-Romeinse gebied rondom die Middellandse See bedoel word;

(ii) die wêreld wat deur Satan beheers word, die demoniese wêreld in sy politieke verskyningsvorm. Dis hierdie laaste oikouéne se mag en heerlikheid wat Satan vir Jesus aanbied in die versoeking, en as Jesus dit nie weerstaan het nie, sou Hy die aanvoerder van die antigoddelike opstand in die wêreld geword het.

Met verwysing na Openbaring 3:10, 13:2, 17:12 en 13:17 argumenteer Beyerhaus verder, sal die mislukte oogmerk van Satan met sy versoeking van Jesus, aan die einde van die tyd tog ten uitvoer gebring word in die heerskappy van die Antichris. As hierdie tyd van diepe nood sy hoogtepunt bereik, sal Christus kom om die ryk van Satan vir ewig uit te wis en dan sal Hy self ten oikouménen méllousan bring. Die ware ekumene waarvan die Nuwe Testament praat, is dus iets van die toekoms wat ons verwag en dit is ' $n$ duiwelse versoeking as die kerk vergeet dat hy uit die wêreld uitgeroep is en in plaas daarvan homself verstaan as 'n godsdienstige suurdeeg of as kultiese kristallisasiepunt van 'n kulturele en politieke wêreldorde.

Vir hom lê die groot ontsporing van die Wêreldraad van Kerke daarin dat dit nie meer kerksentries, maar kosmiessentries dink, veeleer geïnteresseerd is in 'n wêreldbroederskap van alle mense en gelowe, en nie meer in die eenheid van die kerk nie. Na my mening het Beyerhaus met hierdie kritiek van hom die kol wel deeglik getref. Calvyn het beslis nooit in hierdie rigting van die Wêreldraad gedink nie.

Behalwe die twee betekenisse wat die woord ekumene kan hê soos deur Beyerhaus uiteengesit, het daar in die loop van die tyd vier ander betekenisse navore gekom. Twee daarvan leef veral in die oudkerklike spraakgebruik en beteken dít wat betrekking het op die kerk in sy geheel in die wêreld en wat algemene kerklike geldigheid besit. In hierdie sin is daar van die konsilies gepraat. Die laaste twee het te doen met die ekumeniese opvatting van ons tyd, veral vóór die afwykings wat vanaf 1961 aan die lig begin tree het. Dit het te doen met wat betrekking het op die verhouding tussen verskillende kerke of Christene van verskillende belydenisse, en wat uitdrukking gee aan die bewussyn van verlange na Christelike eenheid (W Nijenhuis, Calvinus Oecimenicus, 1959, p 4).

Wanneer ons in hierdie voordrag praat oor Calvyn en die ekumene, wil ons niks meer en niks minder probeer aantoon as hoe Calvyn gedink het oor die eenheid van die kerk en wat hy alles gedoen het om daardie eenheid te bevorder.

\section{Ekumeniese bemoeienisse.}

Calvyn se ekumeniese bemoeienisse is nie los te maak van sy onvermoeide ywer om die Reformasie deur te voer nie en daardeur die 
kerk te vernuwe nie. Die ekumeniese moment in sy kerklike handeling is nie iets waaraan Calvyn benewens ander sake ook aandag gegee het nie. Gottfried W Lochner is reg as hy sê dat Calvyn 'n ekumeniese figuur is, 'n ekumeniese denker en 'n indrukwekkende ekumeniese organisator. Alles wat hy sê en wat hy skryf en wat hy doen, staan in die lig van die ekumene, in onuitgesproke, maar bewuste en daarom in vanselfsprekende samehang met die hele kerk in die hele wêreld (Calvin Anwalt der Ökumene, EVZ, 1960, s 8). Nooit was dit die gedagte van Calvyn om met sy reformasie die kerk te skeur, of om homself van die kerk af te skei nie of om 'n nuwe kerk in die lewe te roep nie. Dit het vir hom nie gegaan om 'n nuwe kerk nie, maar om die kerk opnuut. Hoewel dit ook die standpunt was van die ander twee groot hervormers, het niemand die saak hartstogteliker verdedig as Calvyn nie. As dit waar sou wees, erken hy teenoor Sadolet, dat die reformasie ' $n$ verskeuring van die bruid van Christus sou wees, dan sou Sadolet en die hele wêreld die hervormers met reg as verlore kon beskou het. By niemand van die reformatore staan die kerk so sentraal as by Calvyn nie. Waar by Luther die siel, by Zwingli die volk sentraal staan, daar staan hy Calvyn die kerk as stigting van die Heer en as moeder van al die gelowiges in die middelpunt. Niemand van al die reformatore het hom dan ook meer beywer vir die ordelike opbou van die Kerk as Calvyn nie.

Die vestiging van die gereformeerde gedeelte van die kerk van die reformasie, was anders as die van Lutherse gedeelte. Noordmans tipeer die totstandkoming van die Lutherse kerke as teritoriaal, want dit was verskillende Duitse state wat van tyd tot tyd tot die reformasie oorgegaan het. Die gereformeerdes daarenteen was 'n onbeskermde minderheid wat onder swaar onderdrukking gegroei het. Alles wat gedoen moes word moes die kerk self doen en daarom was dit so nodig dat goed-geordende gemeentes in die lewe geroep word.

Omdat hy self ' $n$ vlugteling was wat toevallig in Geneve sy standplaas gevind het terwyl hy op pad was na Straatsburg, het Calvyn die nood en die behoeftes van die vlugtelinge van die geloof geken. Daar in Geneve het hy aan hierdie daklose gelowiges 'n tuiste geskep het hy hulle onderrig in die leer van die Heilige Skrif en het hy hulle geoefen in 'n christelike lewe (Noordmans, het Calvinisme en de Oekumene, Zoeklichten, 1949, p 202). Die Calvinistiese kerk ontstaan uit hierdie heldhaftige poging van Calvyn deurdat hy hierdie verstrooide Protestante versamel. Daarom begin Noordmans ook sy artikel met die uitspraak dat die Calvinisme reeds kragtens sy oorsprong ' $n$ ekumeniese beweging is.

Vanuit Geneve het die Calvinistiese invloed uitgestraal oor die hele Europa, soos elektriese kragdrade vanuit 'n kragstasie. Geneve was geografies uitnemend geskik om as geestelike kragstasie van die 
Calvinisme te dien. Nie alleen is hy geleë aan water- en landpaaie wat na verre gebiede voer nie, maar hy is ook die poort na Italië, Frankryk en Suid-Duitsland. Om hom te beïnvloed om terug te keer na Geneve, skryf die predikante van Zürich in 1941 aan Calvyn (A L Herminjard, 1 c, vii, p 77 gesiteer deur Nijenhuis, aw p 104) “U weet dat Geneve aan Frankryk, Duitsland en Italië grens, dat daar groot verwagting bestaan dat die evangelie hom vandaar oor die aangrensende stede sal verbrei en dat die grense van die ryk van Christus uitgebrei sal word. U weet dat die Apostel vir hom groot stede uitgesoek het waarin hy die evangelie verkondig het sodat dit van daaruit maklik na ander, naburige stede sou verbrei. Hoe baie $u$ vanuit hierdie stad kan bydra tot die ware ryk van Christus, nie alleen deur $u$ prediking nie, maar ook in geskrifte, weet u self die beste."

En inderdaad het Calvyn dan ook vanuit hierdie stad in korrespondensie gestaan met die ganse Protestantse deel van Europa. Vlugtelinge wat ' $n$ heenkome in Geneve gevind het, het nie alle bande met die tuisgebiede verbreek nie. Op hierdie wyse het Calvyn bekend geword en is hy allerweë erken as die groot leraar van die Calvinistiese kerke. Van oral af is daar raad gevra en aan almal is daar raad gegee. Die pos het sy briewe nie net na Zurich en Wittenberg geneem nie, maar ook na Frankryk, Engeland, Pole, Hongarye, Italië. Hoewel Calvyn baie studeer het, is al sy tyd nie net in die studeerkamer deurgebring nie. Hy het nog tyd vir reise gehad, hoewel hy nie daarvan gehou het nie. As hy egter iets kon doen vir die vervolgdes het hy dit altyd as opdrag aanvaar en na die verskillende godsdiensgesprekke gegaan, soos die in Hagenau(1540), Worms (1540/41) en die een te Regensburg (1941). Sy deelname aan die gesprekke op hierdie byeenkomstes was nie baie ywerig nie, maar in beginselsake het hy die medebroeders tog altyd bygestaan. Twee dinge was wel belangrik wat uit hierdie gesprekke met RoomsKatolieke voortgekom het:

(i) dit was goeie kontakplekke met ander Protestante. So het die ontmoeting tussen Calvyn en Melanchton bv plaasgevind wat gelei het tot 'n langdurige vriendskap.

(ii) Ons leer ook Calvyn se houding teenoor die Rooms-Katolieke kerk baie duidelik. Vir hom was sy bekering eintlik 'n bevryding uit die bygeloof van die Roomse kerk en daarom was enige kompromie met hierdie kerk by hom by voorbaat uitgesluit. Calvyn het dan ook nie nagelaat om sy bedenkings uit te spreek oor die poging van Bucer op die Regensbergse samespreking om deur gekunstelde formuleringe te trag om ooreenstemming te bereik. Wat hy hieroor gesê het, bly vir ons vandag ook nog waar: As ' $n$ mens nie eens is oor die wese van ' $n$ saak nie, moet 'n mens nie die skyn van eenheid bewerk deur kunsmatige terminologie nie. 
Ons het reeds daarop gewys dat die begin van die Calvinisme onlosmaaklik verbonde is met die versameling en versorging van vlugteling Protestante rondom Woord en Sakrament as die wesenlike kenmerke van die ware kerk. Hierdie vlugtelinge het uit verskillende lande gekom en hulle saamvoeging in vlugtelinggemeentes het nie plaasgevind sonder stryd en onenigheid nie. 'n Groot deel van Calvyn se werksaamheid, van sy reise en sy briewe was bedoel om sulke strydpunte uit die weg te ruim. Ons dink hier veral aan sy reise en briewe aan Frankfurt aan die Main. 'n Mens moet jou verbaas dat Calvyn wat so heftig kon reageer tog met soveel eindelose geduld en selfvergetende opoffering gepoog het om versoening te bewerkstellig tussen twistende broeders. Hierdie versoeningspogings is nie beperk tot individue nie, maar sluit ook kerke in. En in hierdie verband is daar twee kerklike groepe wat veral op die voorgrond tree en wat meer as iets anders Calvyn se aandag in beslag geneem het. Ons bedoel die versoeningspogings met en tussen Zwingliane en Lutherane. Dit het in hierdie verband veral gegaan om verskil van opvatting oor die betekenis van die nagmaal. Dit was vir Calvyn 'n treurige saak dat die nagmaal wat juis ' $n$ teken van eenheid moes wees 'n oorsaak van verdeeldheid geword het onder die kinders van die Reformasie. Aan die een kant het Calvyn te doen gehad met die volgelinge van Zwingli in Zürich met hulle simboliese, sinnebeeldige opvatting van die nagmaal. Die nagmaal is nie méér as 'n herinneringsmaal aan die dood van Christus en 'n liefdesmaaltyd van die gelowiges nie. Christus is nie werklik teenwoordig nie en hulle wil van geen krag hoegenaamd weet wat aan die elemente verbonde is nie. Hierdie opvatting van die Zwingliane was 'n reaksie, nie net teen Rome nie, maar ook teen die Lutherane. Volgens hulle (Lutherane) nagmaalsopvatting is die liggaam en bloed van Christus in, met ' $n$ onder die elemente aanwesig. Vir Luther het dit gegaan om die reële teenwoordigheid van die hele Christus na sy Goddelike en menslike natuur.

Calvyn beskou Zwingli se simboliese nagmaalsopvatting as profaan, omdat hy die krag van die teenwoordigheid van Christus in die nagmaal verwerp. Daardeur word die troos van die teenwoordigheid van Christus in die nagmaal weggeneem. Onvermoeid het Calvyn gestrewe om die verdeeldheid rondom die nagmaalsopvatting uit die weg teruim. Aanvanklik het sy onderhandelings en korrespondensie met Bullinger nie veel opgelewer nie, maar met groot geduld het hy tog volgehou in sy poging om die Zürichters tot ander insigte te bring. Wat hy voortdurend beklemtoon het was dat die nagmaal tog iets meer as simboliese handeling is en dat daar ook ' $n$ innerlike werking van Gods genade verbind is deur die Gees met die uitwendige tekens. As Calvyn die teenstander teen die Lutherse beskouing by Bullinger cs kon neutraliseer, sou die onderhandelinge beslis suk- 
sesvoller gewees het. Maar Luther se heftige aanvalle op die beskouing van Zwingli, veral vervat in sy "Korte belydenis aangaande die nagmaal" 1544, het so 'n reaksie in Zürich tot gevolg gehad dat 'n paar Calvinistiese predikante uit die stad gedryf is. Toe Calvyn dit hoor het hy en Faral dadelik na Zürich vertrek, maar so groot was die afkeer dat geen openhartige gesprek kon plaasvind nie. Teleurgesteld het Calvyn teruggekeer na Geneve en dadelik die korrespon- densie met Bullinger hervat. Groot was sy blydskap toe hy ' $n$ jaar later by Bullinger groter begrip vir sy bedoelings opgemerk het. Onmiddellik het hy weer na Zürich vertrek. Hierdie keer was die samesprekings vrugbaar en het uitgeloop op die opstel van ' $n$ ooreenkoms, bekend as die Consensus Tigurinus. Die ooreenkoms, lewer bewys van die ekumeniese gees van Calvyn. Hy het nie ten koste van alles sy opvatting probeer deurdruk nie. By die formulering het hy afgesien van sekere uitdrukkings. Die saak was vir hom baie belangriker as die formulering daarvan. Hy was tevrede dat Bullinger aanvaar het dat God deur sy Gees die genade aan die tekens verbind vir elkeen wat gelowig deelneem aan die nagmaal, sonder dat daar sprake is van materiële verbinding tussen die liggaam en bloed van Christus met die brood en die wyn.

Dankbaar (aw p 168) noem die Consensus Tigurinus 'n ekumeniese daad van enorme betekenis. Daarmee het Calvyn die eenheid van die gereformeerde Protestantisme gered. Van nou af kon die geestesstroming van die Calvinisme as 'n geheel gesien word.

Calvyn se eintlike oogmerk was die versoening tussen Zwingliane en Lutherane. Hy het gereken dat die ooreenkoms met Bullinger groter begrip ook by die Lutherane ten gevolg sou hê. Hierin is hy egter teleurgestel. Van die kant van die Lutherane was daar felle kritiek teen die Consensus. Calvyn het hom hierdeur nie van stryk laat bring nie, maar sy bemoeienisse geïntensifiseer. Met die Lutherse beskouing oor die realiteit van die teenwoordigheid van Christus in die nagmaal, het hy saamgestem, hoewel hy verskil het oor die wyse van teenwoordigheid. Die materiële wyse waarop die Lutherane die teenwoordigheid voorstel het vir hom egter ' $n$ te gevaarlike verwantskap met die beskouing van Rome getoon. Die verskil in opvatting tussen hom en die Lutherane was vir hom egter nie genoeg rede vir verdeeldheid nie. Calvyn se tegemoetkomenheid teenoor die Lutherane blyk ook uit sy beskouing oor die Confessio Augustana. Al sou hy baie dinge anders gesê het, vind hy daarin tog niks wat nie met sy eie opvattings ooreenstem nie. Dieselfde openheid was daar egter nie by sy Lutherse gespreksmaats, byvoorbeeld Melanchton nie. Hoewel daar'n langdurige vriendskap tussen hulle bestaan het, was daar by Melanchton tog nie dieselfde openheid vir Geneve as wat daar by Calvyn was vir Wittenberg nie. Nijenhuis (aw p 223) noem 
twee faktore wat 'n ooreenkoms met die Lutherane in die weg gestaan het:

1. Die spanning wat daar tussen die Lutherane self bestaan het. Al sou Calvyn 'n ooreenkoms met Melanchton bereik het, sou dit nog nie beteken het dat die hele Lutherdom daarby ingesluit is nie.

2. Die vyandige houding wat daar nog altyd tussen Zürich en Wittenberg bestaan het. In sy bemoeienis met die Lutherane het Calvyn geen steun van die kant van Bullinger gekry nie. 'n Ooreenkoms met die Lutherane sou waarskynlik die ooreenkoms met die Zwingliane weer ongedaan gemaak het.

Calvyn het alles probeer om tot 'n vergelyk te kom. Sy laaste poging was 'n godsdiensgesprek, maar ook dit het misluk. Die stryd met die opvolgers van Luther wat van baie kleiner formaat as Luther self was, was baie onverkwiklik. Calvyn het in wanhoop eenmaal uitgeroep: $O$ Luther, hoe min navolgers van $u$ voortreflikheid en hoe baie ape van $u$ heilige grootspraak, het $u$ nagelaat. Hoewel sy pogings misluk het, is sy ekumeniese strewe tog baie duidelik. Pragtig word die grond van die ekumeniese eenheid beskrywe in die Twede verdediging teen Westphal, wat opgedra is aan al die Lutherse predikante:

Oor die een God en die ware en regte wyse om Hom te dien, oor die verdorwenheid van die menslike natuur en die saligheid uit genade, oor die manier waarop regverdiging verkry word, oor die amp en die werk van Christus, oor die bekering en sy uitwerking, oor die geloof wat vir ons heilssekerheid skenk, oor die gebed en oor alle ander hoofpunte word immers oral by ons dieselfde verkondig. Ons roep die een God, ons Vader, aan in vertroue op dieselfde Middelaar; dieselfde Gees van die aanneming tot kinders is vir ons 'n onderpand van ons toekomstige erfenis, deur dieselfde offer het Christus ons almal versoen, op dieselfde geregtigheid wat $\mathrm{Hy}$ vir ons verwerf het, vertrou al ons harte en ons beroem ons op dieselfde Hoof. Dan sou dit tog eienaardig wees as Christus, wat ons almal as ons Vrede prys, wat aan alle vyandskap 'n einde gemaak het en God in die hemele met ons versoen het, nie ook sou maak dat ons hier op aarde 'n broederlike vrede onderhou nie (Dankbaar aw p 170/1.)

Uit hierdie tyd (1552) dateer ook die voorstel van die Anglikaanse biskop, Thomas Cranmer, vir 'n ekumeniese kongres.

Calvyn het die gedagte entoesiasties ondersteun met die klassieke uitspraak dat hy persoonlik bereid sou wees as hulle hom nodig het, om desnoods tien seë oor te steek. Ongelukkig het dieselfde entoesiasme by Bullinger en Melanchton ontbreek sodat van die voorstel van Cramner uiteindelik niks gekom het nie.

Uit hierdie kort historiese oorsig van Calvyn se ekumeniese be- 
moeienisse en betrekkings, word enkele sake duidelik. (Oor die grense van sy eie Geneve heen het Calvyn hom een gevoel met almal wat die evangelie glo en daarvolgens wil lewe, en aan hierdie eenheidsgevoel het hy probeer uitdrukking gee. Voorop het by hom gestaan dat die eenheid van die kerk in Christus 'n gegewe werklikheid is, en hierdie eenheid het hy probeer verwesenlik. Wanneer die hoofsake van die geloof bedreig word, naamlik die geloof in een God en in Jesus Christus die Seun van God, die geloof dat 'n sondaar alleen deur die genade van God geregverdig word, het Calvyn verbete gestry om dit te handhaaf. Aan die ander kant het sy groot ywer en liefde vir die een kerk van die Here hom tog oor kleinere klowe van skeiding laat heenstap, solank die hoofpunte van die geloof net nie in gedrang kom nie.)

\section{Fondament en karakter van Calvyn se eenheidsvisie.}

Om die ekumeniese gesindheid en ingesteldheid, sowel as die aard en karakter daarvan reg te verstaan, is dit nodig om enkele kernsake in die teologiese denke van Calvyn uit te lig. 'n Mens kan dit beswaarlik doen sonder om eers te wys op die ontsaglike betekenis en invloed wat sy "Onderrig in die Christelike Godsdiens" deur al die eeue vir die reformatoriese Christenheid gehad het. Miskien moet die skrywe van hierdie leerboek nog as die grootste ekumeniese daad van Calvyn beskou word. Hy het voorkom dat die christendom van die protestantse vlugtelinge wat die kerk moes verlaat en hulle as't ware onder die blote hemel bevind het, vervloei. Hulle was individue uit verskillende lande en uit verskillende tradisies, hulle het nie eenders gedink nie, daar was verskillende strominge onder hulle. Calvyn het met sy Institusie orde en eenheid gebring in hulle godsdienstige denke. Die Institusie is niks anders as die samevatting van sy Skrifuitleg soos vervat in sy kommentare. 'n Ware en egte teologie van die Woord, is die Institusie. In hierdie boek is die lyne aangedui waarvolgens die kerk onder die verstrooide vlugtelinge opgebou kon word.

Teologie is vir Calvyn 'n werksaamheid wat verrig word uitsluitlik vir die opbou van die kerk. Calvyn se teologie is kerklike teologie. Daarom neem die kerk ook so 'n belangrike plek in in sy teologiese denke. Wat Calvyn dink van die kerk en die groot liefde wat hy het vir hierdie bruid van Christus, is seker die grootste en belangrikste dryfkrag agter sy onvermoeide stryd vir die eenheid van die kerk. Miskien nog meer as wat dit die geval was met Luther en Zwingli het Calvyn oor die verhouding tussen God en mens nie individualisties nie maar kerklik gedink (Nijenhuis, aw p 275).

Calvyn praat oor die kerk in tweërlei sin. Hy praat van die sigbare en van die onsigbare kerk, maar altyd van dieselfde kerk. Met hier- 
die twee aanduidings van die kerk grens hy hom af na twee kante: na die Roomse Kerk en na die sektariese geesdrywers. Wat Rome betref, grens hy hom af teen 'n massale objektiwiteit: Rome identifiseer die kerk as instituut met die kerk van Christus, menslike gesag met God se gesag. Rome identifiseer die hiërargies georganiseerde kerk onder die primaat van die biskop van Rome en wat as 'n heilsinstelling oor die sakramente beskik, met die kerk van Christus wat alleen deur God geken word omdat hy in die verkiesing van God gegrond is. By die geesdrywers word die subjektiewe kant van die kerk weer verkeerd beklemtoon, sodat godsdienstige ervaring gelykgestel word met die werk van die Heilige Gees. Objekíiewe gesag van die kerk word individualisties ontken.

In albei hierdie maniere waarop Calvyn oor die kerk dink, gaan dit om die eenheid. Calvyn ken net een kerk, 'n kerk wat sy eenheid in Christus het. In Institusie iv, 1,2 sê Calvyn dat dit nie genoeg is dat ons in ons gedagtes en gees vashou aan 'n skaar van uitverkorenes nie, tensy ons dink aan so' $n$ eenheid van die kerk waarin ons na ons oortuiging waarlik ingeplant is. Want as ons nie onder Christus, ons Heer, verenig is met al die ander lidmate nie, is daar vir ons geen hoop op die toekomende erfdeel nie.

Daarom word hy katoliek of algemeen genoem, omdat daar nie twee of drie kerke kan wees nie, sonder dat Christus verskeur word nie, wat onmoontlik is. Ja, die uitverkorenes van God is almal in Christus só verbonde, dat hulle, net soos wat hulle een Hoof het, net so ook as't ware saamgroei tot een liggaam, en met so 'n verbinding met mekaar saamhang soos die ledemate van dieselfde liggaam. In waarheid het hulle een geword, aangesien hulle deur een geloof, hoop en liefde, en deur dieselfde Gees van God saamlewe, geroep, nie net tot dieselfde erfenis van die ewige lewe nie, maar ook tot die gemeenskap van die een God en Christus. So praat Calvyn dan oor die eenheid van die onsigbare kerk, 'n eenheid wat in Christus gegee is.

In hierdie aanhaling uit die Institusie moet dit onderstreep word dat Calvyn die eenheid in waarheid en in geloof vind. ' $n$ Mens sou dit die hart van Calvyn se leer oor die eenheid van die kerk kan noem. Dit loop soos 'n rooi draad deur die denke, spreke en handeling van die man van Geneve. Die waarheidsvraag is die kern van die eenheid van die kerk. "Vir Calvyn was die Woord van God, die evangelie van Christus, die pura et sana doctrina die wesenlike kenmerk van die kerk en die fondament van sy eenheid." (Nijenhuis, aw p 301) In geen ander eenheid was Calvyn geïnteresseerd nie. Hy het dan ook nie verskille met allerlei kompromisformules probeer oorbrug nie, maar as daar eenheid in die waarheid was, het hy ook nie weer so onbeweeglik op sy eie formulering van daardie waarheid gestaan nie. Daarom sal ' $n$ mens hom ook nooit kan beskuldig dat hy 
onkonfessioneel gehandel het nie hoewel hy nooit van konfessionalisme beskuldig kan word nie.

Ook as Calvyn oor die sigbare kerk praat wat uit alle volke versamel is, wat versprei en verstrooid deur plaaslike afstande woon, aksentueer hy die eenheid, en netsoos in die geval van die onsigbare kerk is hierdie eenheid in die waarheid gegrond. Aan hierdie eenheid in die waarheid moet vasgehou word wat duiwelse geeste altyd wou verskeur (Inst iv, 1,9). Tussen die eenheid van die sigbare en die onsigbare kerk, is daar slegs hierdie een verskil: laasgenoemde is 'n gegewe werklikheid in Christus, eersgenoemde is 'n doel en 'n taak waarvoor die kerk gestel is.

\section{Die grense van die ekumene.}

Met Calvyn se afgrensing teenoor die Roomse Kerk en die geesdrywery het ons ook by die grense van die ekumene in die denke van Calvyn gekom.

Calvyn se groot beswaar teen hierdie twee instansies is dat hulle Gees en Woord skei. Nêrens het Calvyn helderder oor die saak gespreek as in sy antwoord aan Sadolet wat beweer het dat die onfeilbaarheid en die eenheid van die kerk gefundeer is in die feit dat hy van die begin af gelei is deur die Heilige Gees. Calvyn stel teenoor hierdie argument die getuienis van die Skrif dat God altyd die leiding van die Gees aan die Woord gebind het. Wanneer die Woord verwaarloos word, kom die suiwere leer, die suiwer evangelie, die onderrig van die Skrif in die gedrang. Die Reformasie is juis daarop gerig om die waarheid van die Skrif, die suiwere en gesonde leer te herstel, want die eenheid van die kerk is geleë in die gehoorsaamheid aan God se Woord. Presies dieselfde dinge waardeur Calvyn hom een voel met Zwingliane en Lutherane, vorm vir hom 'n skeidende grens teenoor die Roomse Kerk.

So gesien is sulke grense vir die eenheid van die kerk wesensnoodsaaklik. Omdat dit vir Calvyn in sy ekumeniese strewe nie daarom gaan dat meer of minder mense saamgevoeg word nie, maar daarom dat mense deur gehoorsaamheid aan Gods Woord deur die geloof saamgevoeg word in die Kerk van die Here, is sulkes uitgesluit wat hierdie Woord verwerp. Die Roomse Kerk wat die Woord verwaarloos is dus nie waarborg vir eenheid nie, maar eerder oorsaak van verstrooiing. Calvyn beskou die reformasie as ' $n$ daad van versameling en vereniging uit die verstrooiing van die Roomse Kerk.

As Calvyn die pousdom as die een grens van die ekumene stel, bedoel hy nie daarmee almal wat aan die Roomse Kerk behoort nie, maar slegs die kerk as instituut. Die genade het so gestol geraak in die Roomse Kerk en Christus so 'n gevangene, dat die geloof in 
Christus as Heer van die kerk plek gemaak het vir die geloof in die Kerk self (G.W. Lochner, aw s 24).

Die ander afgrensing is teen die Anabaptiste en die antitrinitariërs. Waar eie godsdienstige ervaring gelykgestel word met die werk van die Heilige Gees, moet dit noodwendig daartoe lei dat die geloof in die mens self in die plek van die geloof in die Heer gestel word.

Omdat albei Gees en Woord uitmekaar ruk, beskou Calvyn hulle albei as sektes: die Roomse Kerk sowel as die spiritualiste en die antitrinitariërs. Die spiritualiste word deur hom egter nog 'n bietjie laer gegradeer as die Roomse Kerk, omdat by l.g. nog dowwe spore van die kerk gevind word, soos b.v. in die doop. Dit was 'n baie skerpsinnige vinding van Calvyn toe hy aangetoon het dat daar slegs skynbaar teenstellings tussen die Roomse Kerk en die sektedom is. Die ooreenkoms tussen die twee lê daarin dat albei die Heilige Gees in hulle mag probeer kry. By die Roomse Kerk word die Gees in die mag van die leeramp vasgevang, en by die spiritualiste in die individuele gewete (Locher, s 25) Miskien is dit beste om maar weer te gaan luister wat Calvyn in hierdie verband aan Sadolet skryf:

Die kerkvader Chrysostomus het reg met sy vermaning as hy almal afwys wat ons onder die voorwendsel van die Gees van die eenvoudige leer van die evangelie wil weglei. Want die Gees is nie aan ons beloof om 'n nuwe leer te openbaar nie, maar om die evangeliese waarheid in die harte van die mense te verdiep. In die huidige toestand merk ons iets van die noodsaaklikheid van hierdie vermaning. Ons word naamlik deur twee sektes aangeval wat skynbaar hemelsbreed van mekaar verskil. Want waarin is daar ooreenkoms sover dit die uiterlike betref tussen die van die pous en die wederdopers? En tog - daaraan kan jy leer dat die duiwel hom nooit so geslepe kan vermom dat hy hom tog nie so effens kan verraai nie: albei gebruik dieselfde hoofwapen teen ons. As hulle naamlik tot vervelenstoe kwistig met "Gees" besig is, wil hulle daarmee niks anders doen nie as om op die graf van die onderdrukte Woord van God hulle eie leuengebou op te rig nie. (Joannis Calvini Opera Selecta Edidit Petrus Barth et Duilelmus Niesel. Volumen 1 p 465) (Gesiteer by Locher.)

\section{Korrektiewe riglyne vir die toekoms.}

Ons ondersoek na Calvyn se beskouing oor die eenheid van die kerk sal sekerlik nie volledig wees as die ekumeniese situasie in die wêreld en in ons eie land nie in die lig van ons bevinding krities beskou word nie. Wend ons ons tot die ekumeniese strewe van die Wêreldraad van Kerke vandag, is daar weinig van die grondslae en 
motiewe van Calvyn nog merkbaar. Verwys word na twee tendense wat sedert Nieu-Delhi sterk navore gekom het:

(i) 'n Weg beweeg van evangelisasie na humanisasie; 'n uitsluitlike betrokkenheid by sosiopolitieke sake en nie by die saak van die evangelie nie. Noordmans wys daarop dat die groot vraag vir die toekoms van die kerk en die ekumene is, met wie ons op die pad wil gaan: met God of met die mens. Calvyn het in sy uitverkiessingsleer bely dat hy met God wil gaan. Die uitverkiesing bring die troos vir 'n mens dat jou toekoms nie van mense kom nie, maar van God. Wie met God gaan, gaan in gehoorsaamheid aan sy Woord, gaan in die geloof, gaan met die suiwere en gesonde leer van die evangelie. Calvyn wil in die ekumene die volle ruimte laat vir die regering van God deur sy Woord. Die strewe van die Wêreldraad is baie duidelik om die wêreld nie te vul met die gehoorsaamheid aan Gods Woord nie, maar om hom te vul met die mens, met die nuwe humaniteit. Hy wil blykbaar die toekoms met die mens tegemoet gaan. Hy wil die wêreld vol maak met homself en nie met die Woord van God nie. Dit is meer die weg van Rome om die geskiedenis met homself vol te mak. Die weg van Calvyn is dit beslis nie.

(ii) 'n Uitbreiding van die ekumeniese strewe. Dit gaan nie meer om die eenheid van die Christelike kerke nie, maar om 'n eenheid van alle mense van alle gelowe en ideologieë. Die ekumeniese grense van Calvyn, $\mathrm{nl}$ die geloof in die een waarheid wat in Christus geopenbaar word, is hier oorskrei.

Wat die ekumeniese situasie in ons eie land betref, veral ten opsigte van die drie Afrikaanse kerke, wil dit voorkom of Calvyn wel aan ons'n taak stel en sal dit goed wees dat ons voortgaan op die weg wat reeds ingeslaan is. 